\title{
Red blood cell variables in highly trained pubescent athletes: a comparative analysis
}

N Boyadjiev, Z Taralov

\begin{abstract}
Background-A suboptimal haematological status has often been recorded in athletes involved in intensive physical activity. There have even been reports of "sports anaemia" associated with intensive physical exercise. However, studies on the effect of different types of exercise practiced over a long period of time on the red blood cell variables in pubescent athletes are very few.
\end{abstract}

Aim-To assess the basic red blood cell variables in highly trained pubescent athletes from different sports and to compare the results with those for a control untrained group. Sex related differences in these variables were also assessed.

Methods-876 highly trained athletes (559 boys and 317 girls) were included in the study. Their mean (SEM) age, weight, and duration of training were: $14.01(0.06)$ years, $56.24(0.52) \mathrm{kg}$, and $3.52(0.07)$ years respectively. The control group consisted of 357 untrained subjects (171 boys and 186 girls) with mean (SEM) age and weight of $14.58(0.09)$ years and $57.75(0.67) \mathrm{kg}$. The group of athletes was divided into seven subgroups according to the sport practiced: athletics (105), swimming (107), rowing (230), wrestling (225), weight lifting (47), various team sports (92), and other sports (67). Venous blood samples were drawn from the cubital vein, and the red blood cell count, packed cell volume, haemoglobin concentration, and mean corpuscular volume were measured. Statistical indices were computed for each group and for each variable, and analysis of variance factorial analysis was performed to evaluate the statistical significance of the differences detected.

Results-The highly trained group was found to have lower red blood cell count, packed cell volume, and haemoglobin concentration $(p<0.001)$ than the control untrained group $\left(4.61(0.01) \times 10^{12} / 1 v 4.75\right.$ $(0.02) \times 10^{12} / 1,0.389(0.001) v 0.404(0.002)$ $1 / 1$, and $133.01(0.38)$ v $139.9(0.62)$ g/1 respectively). These variables were lower for the boys of the trained group than for the boys of the control group $(p<0.001)$, and similarly for the girls $(p<0.001)$. The lowest red blood cell count, packed cell volume, and haemoglobin concentration were measured in blood samples from the boys of the swimming subgroup (4.54 $(0.06) \times 10^{12} / 1,0.386(0.006) 1 / 1$, and 129.38 (1.80) $\mathrm{g} / 1$ respectively) and the rowing subgroup $\left(4.66(0.03) \times 10^{12} / 1,0.400(0.003)\right.$
$1 / 1$, and $136.21(0.94)$ respectively). The same distribution was found for the girls: lowest in the rowing subgroup $(4.32(0.04)$ $\times 10^{12} / 1,0.314(0.003) 1 / 1$, and $124.27(0.93)$ g/1) and the swimming subgroup $(4.40$ $(0.05) \times 10^{12} / 1,0.375(0.005) 1 / 1$, and 125.90 (1.30) $\mathrm{g} / 1$ ). No differences were found in the mean corpuscular volume.

Conclusions-Continuous (more than one year) high intensity sports training (twice a day/five days a week) results in a decrease in the basic red blood cell variables in pubescent boys and girls, this being most pronounced in the submaximal sports.

(Br F Sports Med 2000;34:200-204)

Keywords: erythrocytes; haemoglobin; packed cell volume; mean corpuscular volume; pubescence; training

There have been frequent reports of a suboptimal haematological status being observed in athletes involved in intensive physical activity. ${ }^{1}$ There have even been reports of "sports anaemia" resulting from intensive physical exercise in humans ${ }^{2-4}$ as well as in experimental animals. ${ }^{5}$ Some of these studies have investigated the acute effects of different types of exercise on red blood cell variables. The effects found have been a decrease in red blood cell count, haemoglobin concentration, packed cell volume, mean corpuscular volume, and mean haemoglobin concentration, ${ }^{6-10}$ or with an increase in red blood cell count. ${ }^{11}{ }^{12}$ Other studies have centred on the effects of chronic high intensity training on these variables. ${ }^{1-3} 1314$ However, there are few studies on the effect of different types of long term exercise on red blood cell variables, ${ }^{1}$ especially in pubescent highly trained athletes.

The aim of this study was to measure and assess the basic red blood cell variables in highly trained pubescent athletes from different sports and to compare these results with those for a control untrained group. Sex dependent variations in these variables were also looked at.

\section{Materials and methods}

SUBJECTS

A total of 876 highly trained athletes ( 559 boys and 317 girls) from sports schools in Bulgaria were recruited for the study. The subjects were $14.01(0.06)$ years old, $165.51(0.44) \mathrm{cm}$ tall, weighed $56.24(0.52) \mathrm{kg}$, and had trained for 3.52 (0.07) years (all values means (SEM)). They were allocated to seven subgroups according to the sport they practiced: field and track athletics (sprinting) (105), distance 
Table 1 General characteristics and red blood cell variables of the highly trained and untrained groups

\begin{tabular}{|c|c|c|c|}
\hline Variable & $\begin{array}{l}\text { Highly trained group } \\
(n=876)\end{array}$ & $\begin{array}{l}\text { Untrained group } \\
(n=357)\end{array}$ & $p$ Value \\
\hline Age (years) & $14.01 \quad(0.06)$ & $14.58(0.09)$ & NS \\
\hline Weight (kg) & $56.24 \quad(0.52)$ & $57.75(0.67)$ & NS \\
\hline Height $(\mathrm{cm})$ & $165.51 \quad(0.44)$ & $166.09(0.54)$ & NS \\
\hline Duration of training (years) & $3.52(0.07)$ & - & \\
\hline $\mathrm{RBC}\left(\times 10^{12} / \mathrm{l}\right)$ & $4.61 \quad(0.01)$ & $4.75 \quad(0.02)$ & 0.001 \\
\hline Het $(1 / 1)$ & $0.389(0.001)$ & $0.404(0.002)$ & 0.001 \\
\hline $\mathrm{Hb}(\mathrm{g} / \mathrm{l})$ & $133.01 \quad(0.38)$ & $139.97(0.62)$ & 0.001 \\
\hline $\operatorname{MCV}(\mathrm{fl})$ & $85.22(0.18)$ & $85.24 \quad(0.30)$ & NS \\
\hline
\end{tabular}

Values are mean (SEM). RBC, red blood cell count; Hct, packed cell volume; Hb, haemoglobin concentration; $\mathrm{MCV}$, mean corpuscular volume.

swimming (107), rowing (230), boxing, wrestling, and judo (225), weight lifting (47), soccer, basketball, and handball, referred to as team sports (92), and other sports (gymnastics, rhythmic gymnastics, acrobatics, table tennis, and tennis) (70). The control group consisted of 357 untrained young people (171 boys and 186 girls) matched for age, weight, and height (14.58 (0.09) years, $57.75(0.67) \mathrm{kg}$, and $166.09(0.54) \mathrm{cm})$. The athletes trained five days a week for 90 minutes twice a day. The physical activity of the control group amounted to 90 minutes (two 45 minute periods) a week (moderate intensity exercise in the physical culture classes at school).

RED BLOOD CELL VARIABLES

Venous blood samples were drawn from the cubital vein between 0700 and 0900 in accordance with the guidelines of the Expert Panel on Theory of Reference Values (EPTRV) and International Federation of Clinical Chemistry (IFCC), ${ }^{15} 48$ hours after the last training bout. The samples were collected using Sarstedt closed system needles and placed in tubes containing EDTA (tripotassium salt). Haematological variables including red blood cell count, packed cell volume, haemoglobin concentration, and mean corpuscular volume were analysed on a Coulter analyser (Beckman Coulter Inc, Fullerton, California, USA).

STATISTICAL ANALYSIS

Statistical indices were computed for each group and for all variables (StatView 4.51 statistical software; Abacus Concepts Inc, Berkeley, California, USA). Analysis of variance factorial analysis was used to evaluate the significance of the differences. Correlation analysis was also used to estimate the correlation between some of the variables. All data are presented as mean (SEM). Values at the 0.05 level were accepted as being statistically significant.

\section{Results}

COMPARISON BETWEEN RED BLOOD CELL VARIABLES OF THE TRAINED AND UNTRAINED GROUPS

The trained group had significantly lower values for red blood cell count, packed cell volume, and haemoglobin concentration than the control group $(\mathrm{p}<0.001)$ (table 1$)$. The analysis of variance factorial analysis showed that the factor "sport practicing" strongly affected these variables $(p<0.001)$. The mean values for the trained group were below the lower limits of the reference ranges for the general population of the same age as the sample studied. ${ }^{16}{ }^{17} \mathrm{It}$ was found that active sports training did not affect mean corpuscular volume.

\section{COMPARISON OF RED BLOOD CELL VARIABLES BY} SEX

The variables studied show specific sex related differences for healthy pubescent subjects. Analysis of variance factorial analysis applied to the whole cohort studied indicated a specific distribution by sex for red blood cell count, packed cell volume, and haemoglobin concentration for both the athletes and the control group: the variables were higher in the boys $(\mathrm{p}<0.001)$ than in the girls. No differences were found for mean corpuscular volume (table 2).

The variables were lower in the trained boys than in the untrained boys: by $6.14 \%$ for red blood cell count $(p<0.001)$, by $6.78 \%$ for packed cell volume $(\mathrm{p}<0.001)$, and by $7.21 \%$ for haemoglobin concentration $(p<0.001)$ (all $\mathrm{p}$ values in the following text are derived by analysis of the absolute values presented in tables 2, 3, and 4). For the trained subjects these were below the lower limits of the reference range for boys of the general population of that age. ${ }^{16}$

In the actively training girls, the mean values for the blood variables were also significantly lower than those of the girls of the control group: by $2.04 \%$ for red blood cell count $(\mathrm{p}<0.05)$, by $2.95 \%$ for packed cell volume $(\mathrm{p}<0.001)$, and by $5.61 \%$ for haemoglobin concentration $(p<0.001)$. They were also below the reference values for that age. ${ }^{16}$ As for boys, there were no differences in mean corpuscular volume between the girls of the trained and untrained groups.

COMPARISON OF THE RED BLOOD CELL VARIABLES BY SPORT

Analysis of variance factorial analysis suggested a significant effect of type of sport practiced on

Table 2 Red blood cell variables of pubescent boys and girls from the highly trained and untrained groups

\begin{tabular}{|c|c|c|c|c|c|c|}
\hline \multirow[b]{2}{*}{ Variable } & \multicolumn{3}{|l|}{ Boys } & \multicolumn{3}{|l|}{ Girls } \\
\hline & $\begin{array}{l}\text { Trained } \\
(n=559)\end{array}$ & $\begin{array}{l}\text { Untrained } \\
(n=171)\end{array}$ & $p$ Value & $\begin{array}{l}\text { Trained } \\
(n=317)\end{array}$ & $\begin{array}{l}\text { Untrained } \\
(n=186)\end{array}$ & $p$ Value \\
\hline $\operatorname{RBC}\left(\times 10^{12} / 1\right)$ & $4.72 \quad(0.02)$ & $5.01 \quad(0.03)$ & 0.001 & $4.42 \quad(0.02)$ & $4.51 \quad(0.03)$ & 0.05 \\
\hline Het $(1 / 1)$ & $0.398(0.001)$ & $0.425(0.003)$ & 0.001 & $0.373(0.002)$ & $0.384(0.002)$ & 0.001 \\
\hline $\mathrm{Hb}(\mathrm{g} / \mathrm{l})$ & $136.33(0.45)$ & $146.16(0.82)$ & 0.001 & $127.13(0.57)$ & $134.26(0.67)$ & 0.001 \\
\hline $\mathrm{MCV}(\mathrm{fl})$ & $85.16(0.23)$ & $84.94 \quad(0.40)$ & NS & $85.32(0.27)$ & $85.51 \quad(0.44)$ & NS \\
\hline
\end{tabular}

Values are mean (SEM). RBC, red blood cell count; Hct, packed cell volume; Hb, haemoglobin concentration; MCV, mean corpuscular volume. 
Table 3 Red blood cell variables in the trained boys by sport

\begin{tabular}{|c|c|c|c|c|c|c|c|c|}
\hline \multirow[b]{2}{*}{ Variable } & \multicolumn{8}{|l|}{ Sport } \\
\hline & $\begin{array}{l}\text { Athletics } \\
(n=39)\end{array}$ & $\underset{(n=48)}{\text { Swimming }}$ & $\begin{array}{l}\text { Rowing } \\
(n=122)\end{array}$ & $\begin{array}{l}\text { Wrestling } \\
(n=220)\end{array}$ & $\begin{array}{l}\text { Weight lifting } \\
(n=47)\end{array}$ & $\begin{array}{l}\text { Team } \\
(n=42)\end{array}$ & $\begin{array}{l}\text { Others } \\
(n=40)\end{array}$ & $\begin{array}{l}\text { Control } \\
(n=168)\end{array}$ \\
\hline $\operatorname{RBC}\left(\times 10^{12} / 1\right)$ & $4.84(0.05)^{\star}$ & $4.54(0.06)^{\star \star \star}$ & $4.66(0.03)^{\star \star \star}$ & $4.80(0.03)^{\star \star \star}$ & $4.70(0.05)^{\star \star \star}$ & $4.77(0.06)^{\star \star \star}$ & $4.54(0.05)^{\star \star \star}$ & $5.01(0.03)$ \\
\hline Het $(1 / 1)$ & $0.415(0.004)$ & $0.386(0.006)^{\star \star \star}$ & $0.400(0.003)^{\star \star \star}$ & $0.396(0.002)^{\star \star \star}$ & $0.407(0.004)^{\star \star}$ & $0.397(0.005)^{\star \star \star}$ & $0.387(0.005)^{\star \star \star}$ & $0.425(0.003)$ \\
\hline $\mathrm{Hb}(\mathrm{g} / \mathrm{l})$ & $142.62(1.28)$ & $129.38(1.80)^{\star \star \star}$ & $136.21(0.94)^{\star \star \star}$ & $135.58(0.70)^{\star \star \star}$ & $140.28(1.50)^{\star \star \star}$ & $140.43(1.61)^{\star \star}$ & $134.05(1.36)^{\star \star \star}$ & $146.16(0.82)$ \\
\hline $\operatorname{MCV}(\mathrm{fl})$ & $86.11(0.82)$ & $85.22(0.65)$ & $85.59(0.39)$ & $83.86(0.42)$ & $85.90(0.77)$ & $85.14(0.62)$ & $85.94(0.81)$ & $84.94(0.40)$ \\
\hline
\end{tabular}

Values are mean (SEM).

${ }^{\star} \mathrm{p}<0.05,{ }^{\star \star} \mathrm{p}<0.01,{ }^{\star \star \star} \mathrm{p}<0.001$ compared with controls.

RBC, red blood cell count; Hct, packed cell volume; Hb, haemoglobin concentration; MCV, mean corpuscular volume.

the blood variables for both girls and boys $(\mathrm{p}<0.001)$ (tables 3 and 4$)$.

In the male athletes of all subgroups, red blood cell count was lower than in the control group (for all subgroups except athletics the difference was significant at $\mathrm{p}<0.001$; the difference was significant at $\mathrm{p}<0.05$ for the track and field athletes) (table 3 ). The swimmers and players of other sports had the lowest red blood cell counts, lower on average by $10.35 \%$ than those of the control group. This compares with $7.51 \%$ lower for the rowers, $6.60 \%$ lower for the weight lifters, $5.03 \%$ lower for the players of team sports, $4.38 \%$ for wrestlers, boxers, and judoists, and $3.51 \%$ for track and field athletes. For all the subgroups, the mean value for red blood cell count was below the lower limit of the reference range of the general male population of the corresponding age. ${ }^{16}$

The swimmers also had the lowest haemoglobin concentration: $12.97 \%$ lower on average than that of the control group of untrained boys $(p<0.001)$. In athletes practicing other sports it was lower by $9.03 \%$ than the controls $(\mathrm{p}<0.001)$, in the wrestlers, boxers, and judoists $7.80 \%$ lower than in the controls $(p<0.001)$, in the rowers $7.30 \%$ lower $(\mathrm{p}<0.001)$, in the weight lifters $4.19 \%$ lower $(\mathrm{p}<0.001)$, and in the players of team sports $4.08 \%$ lower $(\mathrm{p}<0.01)$. Haemoglobin concentration in the track and field athletes was lower by $2.48 \%$ on average than that of the control group, but the difference was not statistically significant. In all the subgroups, the mean haemoglobin concentration was below the lower limit of the reference range for the general male population of the corresponding age. ${ }^{16}$

The lowest packed cell volume was found in swimmers: on average, lower by $10.10 \%$ $(p<0.001)$ than that of the control group of boys. Packed cell volumes were higher in the athletes practicing other sports; it was lower by $9.82 \%(\mathrm{p}<0.001)$ than that in the controls, fol- lowed by the wrestlers, boxers, and judoists (lower by $7.32 \%(\mathrm{p}<0.001)$ ), players of team sports (lower by $7.05 \%(\mathrm{p}<0.001)$ ), and the rowers (lower by $6.25 \%(\mathrm{p}<0.001)$ ). Although it was lower by $2.41 \%$ on average, the packed cell volume of track and field athletes was not significantly different from that of the control group. In boys in all the sports subgroups, the mean packed cell volume was below the lower limit of the reference range for the general male population group of this age. ${ }^{16}$

No differences were found between the subgroups with respect to mean corpuscular volume.

In the girls, the lowest red blood cell counts were found in the rowers: on average $4.4 \%$ lower $(p<0.001)$ than for the control group (table 4). The swimmers, track and field athletes, and players of team sports had lower red blood cell counts than the control group; red blood cell count was higher than in the control group in the girls practicing wrestling, boxing, and judo. However, the differences were not statistically significant. The female swimmers, rowers, track and field athletes, and those from team sports had mean red blood cell counts below the lower limit of the reference range of the general female population of this age. ${ }^{16}$

Haemoglobin concentration was lowest in the female rowers, team sport players, and swimmers $\quad(8.04 \% \quad(\mathrm{p}<0.001), \quad 6.72 \%$ $(\mathrm{p}<0.001)$, and $6.64 \%(\mathrm{p}<0.001)$ respectively lower than that of the control group). It was also lower in the track and field athletes, but only by $2.36 \%(\mathrm{p}<0.05)$. The girls doing judo and those in the"other sports" subgroup did not differ from the control group with regard to haemoglobin concentration. The haemoglobin concentration in all the groups was below the lower reference limit for the general female population of the same age. ${ }^{16}$

Packed cell volume was significantly lower than that of the control group in the female

Table 4 Red blood cell variables in the trained girls by sport

\begin{tabular}{|c|c|c|c|c|c|c|c|}
\hline \multirow[b]{2}{*}{ Variable } & \multicolumn{7}{|l|}{ Sport } \\
\hline & $\begin{array}{l}\text { Athletics } \\
(n=66)\end{array}$ & $\begin{array}{l}\text { Swimming } \\
(n=59)\end{array}$ & $\begin{array}{l}\text { Rowing } \\
(n=108)\end{array}$ & $\begin{array}{l}\text { fudo } \\
(n=5)\end{array}$ & $\begin{array}{l}\text { Team } \\
(n=50)\end{array}$ & $\begin{array}{l}\text { Others } \\
(n=27)\end{array}$ & $\begin{array}{l}\text { Control } \\
(n=182)\end{array}$ \\
\hline $\operatorname{RBC}\left(\times 10^{12} / 1\right)$ & $4.47(0.04)$ & $4.40(0.05)$ & $4.32(0.04)^{\star \star \star}$ & $4.70(0.07)$ & $4.47(0.04)$ & $4.61(0.07)$ & $4.51(0.03)$ \\
\hline Het $(1 / 1)$ & $0.383(0.003)$ & $0.375(0.005)^{\star}$ & $0.364(0.003)^{\star \star \star \star}$ & $0.390(0.009)$ & $0.374(0.005)^{\star}$ & $0.377(0.006)$ & $0.384(0.002)$ \\
\hline $\mathrm{Hb}(\mathrm{g} / \mathrm{l})$ & $131.17(0.97)^{\star}$ & $125.90(1.30)^{\star \star \star}$ & $124.27(0.93)^{\star \star \star}$ & $136.80(2.08)$ & $125.82(1.66)^{\star \star \star}$ & $132.07(1.70)$ & $134.26(0.67)$ \\
\hline MCV (fl) & $86.06(0.62)$ & $85.80(0.55)$ & $86.00(0.45)$ & $84.10(0.85)$ & $84.20(0.70)$ & $84.25(0.91)$ & $85.51(0.44)$ \\
\hline
\end{tabular}

Values are mean (SEM)

${ }^{\star} \mathrm{p}<0.05,{ }^{\star \star} \mathrm{p}<0.01,{ }^{\star \star \star} \mathrm{p}<0.001$ compared with controls.

RBC, red blood cell count; Hct, packed cell volume; Hb, haemoglobin concentration; MCV, mean corpuscular volume. 
Table 5 Correlation between the duration of training (years) and the differences in mean values of red blood cell variables of the trained groups compared with the control group

\begin{tabular}{|c|c|c|c|c|c|c|}
\hline \multirow[b]{2}{*}{ Sport } & \multicolumn{3}{|l|}{ Boys } & \multicolumn{3}{|l|}{ Girls } \\
\hline & $R B C$ & $H b$ & $H c t$ & $R B C$ & $H b$ & $H c t$ \\
\hline Athletics & 0.059 & 0.342 & 0.197 & 0.126 & 0.285 & 0.165 \\
\hline Swimming & $0.561^{\star \star}$ & $0.822^{\star \star \star}$ & $0.812^{\star \star \star}$ & -0.172 & 0.075 & 0.069 \\
\hline Rowing & $0.266^{\star}$ & $0.334^{\star}$ & $0.288^{\star}$ & -0.196 & -0.160 & -0.278 \\
\hline Wrestling etc. & 0.191 & 0.249 & 0.191 & $0.263^{\star}$ & $0.833^{\star \star}$ & $0.481^{\star \star}$ \\
\hline Weight lifting & -0.010 & $0.441^{\star \star}$ & 0.565 & - & - & - \\
\hline Team & 0.139 & $0.280^{\star}$ & 0.189 & $-0.375^{\star}$ & $-0.158^{\star}$ & $-0.376^{\star}$ \\
\hline Others & 0.066 & 0.165 & 0.181 & $0.331^{\star}$ & $0.256^{\star}$ & $0.224^{\star}$ \\
\hline
\end{tabular}

Values are correlation coefficients.

Significance of correlation ${ }^{\star} \mathrm{p}<0.05,{ }^{\star \star} \mathrm{p}<0.01,{ }^{\star \star \star} \mathrm{p}<0.001$

RBC, red blood cell count; Hct, packed cell volume; Hb, haemoglobin concentration.

rowers $(\mathrm{p}<0.001)$, team sport players $(\mathrm{p}<0.05)$, and swimmers $(\mathrm{p}<0.05)$.

No differences in mean corpuscular volume were found between the trained and untrained girls.

\section{Discussion}

The results of the present study support the findings reported by a number of authors ${ }^{1-3} 1314$ that the major red blood cell variables undergo a change in athletes (table 1). Analysis of variance factorial analysis indicates that these changes, in both girls and boys, are dependent on the factor "sport practicing". We have also found, in contrast with the findings of Shiga et $a l^{18}$ in pubescent untrained subjects, that there are sex dependent differences in red blood cell count, packed cell volume, and haemoglobin concentration $(\mathrm{p}<0.001)$ in both highly trained athletes and untrained controls: the mean values in boys were higher than in girls (table 2).

We found specific differences in the major red blood cell variables of training pubescent boys and girls in relation to the sport practiced. Schobersberger et $a l^{14}$ found they were lower than normal during systematic strength training exercises, and Biancotti et $a l^{1}$ found the same in endurance training.

The sport related reduction in these variables is similar in boys and girls, which indicates that a particular sport has the same effect in both sexes. Red blood cell count, packed cell volume, and haemoglobin concentration showed the greatest decrease in boys doing swimming and rowing, and this was less in those participating in weight lifting, team sports, wrestling, boxing, judo, and track and field athletics (table 3 ). The largest reduction observed in girls was in the swimmers and rowers, and the smallest in the track and field athletes (table 4). Therefore the conclusion is that swimming and rowing can reduce the basic red blood cell variables much more than other sports in both sexes and may be associated to a greater extent with sports anaemia.

All early and late changes in the haematological variables after acute intensive physical exercise regardless of its characteristics (aerobic, anaerobic, or mixed) are caused by factors associated mainly with the processes of haemoconcentration and haemodilution ${ }^{12}$ and with changes in the plasma catecholamine concentration and the consequences of these. ${ }^{9}$ In chronic daily exercise, continuing for years, changes in red blood cell variables coexist (over the whole period) with training, and the mechanisms involved are probably quite different: chronic intravascular haemolysis, which is associated with strength sports, and changes in serum erythropoietin concentration. ${ }^{12}$ However, the protocol of our study did not allow us to advance enough arguments for any specific mechanism by which we could explain our findings.

The correlation analysis we used showed that in the sportspeople there was a correlation between the duration of training and the reduction in the haematological variables studied, in comparison with the mean values of the control untrained group. The highest correlation coefficients in both boys and girls were found between the duration of sporting activity (years) and the difference in haemoglobin concentration in the blood of the control group (table 5). In male swimmers, $r=0.561$ $(\mathrm{p}<0.01), r=0.822(\mathrm{p}<0.001)$, and $r=0.812$ $(\mathrm{p}<0.001)$ for red blood cell count, haemoglobin concentration, and packed cell volume respectively; in male rowers, $r=0.266$ (p<0.05), $r=0.334(\mathrm{p}<0.05)$, and $r=0.288$ $(\mathrm{p}<0.05)$ respectively. For the female judoists, $r$ $=0.263(\mathrm{p}<0.05), r=0.833(\mathrm{p}<0.01)$, and $r=$ $0.481(\mathrm{p}<0.01)$, while in girls practicing other sports $r=0.331(\mathrm{p}<0.05), r=0.256(\mathrm{p}<0.05)$, and $r=0.244(\mathrm{p}<0.05)$ respectively. These data show a link between the duration of practicing swimming and rowing and the reduction in the blood cell variables in boys, and between the duration of practicing judo and other sports and the decrease in these variables in girls.

\section{CONCLUSIONS}

We found sex related differences in red blood cell count, packed cell volume, and haemoglobin concentration in both the pubescent untrained subjects and the athletes, the values being higher in the boys than in the girls.

Red blood cell count, packed cell volume, and haemoglobin concentration were lower in the athletes than in the untrained subjects. This was true for boys and girls. The variables in all of them were found to be close to or below the lower reference range for the age of pubescence.

A correlation was found between the length a sport had been practiced and the degree of reduction in red blood cell count, packed cell volume, and haemoglobin concentration in pubescent athletes.

Contributors: N P B initiated and coordinated the formulation of the primary study hypothesis, discussed the core ideas in the study and its design, performed the statistical analysis, and wrote and edited the paper. Z P T initiated the research, wrote and edited the paper. $Z \mathrm{P} T$ initiated the research, dat are guarantors of the paper.

1 Biancotti PP, Caropreso A, Di Vicenzo GC, et al. Hematological status in a group of male athletes of different sports. F Sports Med Phys Fitness 1992;32:70-5.

2 Hasibeder W, Schobersberger W, Mairbaurl H. Red cell oxygen transport before and after short-term maximal swimming in dependence on training status. Int 7 Sports Med 1987;8:105-8.

3 Magazanik A, Weinstein Y, Dim RA, et al. Iron deficiency caused by 7 weeks of intensive physical exercise. Eur $\mathcal{F} A p p l$ Physiol 1988;57:198-202.

4 Radomski MW, Sabiston BH, Isoard P. Development of 'sports anemia' in physically fit men after daily sustained submaximal exercise. Aviat Space Environ Med 1980;51:415. 
5 Szygula Z, Spodaryk K, Dabrowski Z, et al. Post-exercise anemia as a result of exercise overloading of the organism

6 Brodthagen UA, Hansen KN, Knudsen JB, et al. Red blood cell 2,3-DPG, ATP and mean cell volume in highly trained athletes. Effect of long-term submaximal exercise. Eur $\mathcal{F}$ Appl Physiol 1985;53:334-8.

7 Cordova Martinez A, Escanero JF. Iron, transferrin, and haptoglobin levels after a single bout of exercise in men. Physiol Behav 1992;51:719-22.

8 Gimenez M, Mohan-Kumar Ò, Humbert JC, et al. Leucocyte, lymphocyte and platelet response to dynamic
exercise. Duration or intensity effect? Eur $\mathcal{F}$ Appl Physiol 1986;55:465-70

9 Laub M, Hvid-Jacobsen K, Hovind P, et al. Spleen emptying and venous hematocrit in humans during exercise. $\mathcal{F} A p p l$ Physiol 1993;74:1024-6.

10 Vogalaere P, Brasseur M, Lecrercq R, et al. Variations hematologiques a l'exercice physique sous maximal delongue tologiques a l'exercice physique sous maximal delong

11 Cordova A, Navas FJ, Escanero JF. The effect of exercise and zinc supplementation on the hematological parameters in rats. Biol Trace Elem Res 1993;39:13-20.

12 Schwandt HJ, Heyduck B, Gunga HC, et al. Influence of prolonged physical exercise on the erythropoietin concentration in blood. Eur f Appl Physiol 1991;63:463-6.
13 Schmidt W, Maassen N, Trost F, et al. Training induced effects on blood volume, erythrocyte turnover and hemoglobin oxygen binding properties. Eur F Appl Physiol 1988;57:490-8.

14 Schobersberger W, Tschann M, Hasibeder W, et al. Consequences of 6 weeks of strength training on red cell $\mathrm{O}_{2}$ transport and iron status. Eur f Appl Physiol 1990;60:1638.

15 IFCC. The theory of reference values. Part 3. Preparation of individuals and execution of blood specimen collection for the production of reference (and observed) values. Clin Chim Acta 1984;139:203F-30F

16 Nathan D, Oski F. Hematology of infancy and childhood. 4th ed. Mexico City: Saunders, 1993:appendix iii.

17 Silver HK, Kempe CH, Bruyn H. Handbook of pediatrics. 9th ed. Los Angeles: Lange Publishers, 1971:165-6.

18 Shiga S, Koyanagi I, Kanuagi R. Clinical reference values for laboratory hematology tests calculated using the integrative truncation method with correction. Part 1. Reference values for erythrocyte count, hemoglobin quantity, hematocrit and other erythrocyte parameters including $\mathrm{MCV}, \mathrm{MCH}, \mathrm{MCHC}$, and RDW [abstract]. fapanese fournal of Clinical Pathology 1990;38:93103.

Take home message

Continuous high intensity sports training over more than one year decreases basic red blood cell variables in pubescent boys and girls, this being most pronounced for submaximal sports. 